\title{
RESENHA. BIOGRAFIA DE MULHERES
}

REVIEW. BIOGRAFIA DE MULHERES

\section{RESEÑA. BIOGRAFIA DE MULHERES}

Ana Carolina Braga de Sousa Universidade Estadual do Ceará, Brasil https://orcid.org/0000-0001-6959-5493 carolbraga30@yahoo.com.br

Márcia Cristiane Ferreira Mendes Universidade Estadual do Ceará, Brasil https://orcid.org/0000-0002-6219-7182 marciacfmendes@gmail.com

Vitória Chérida Costa Freire Universidade Estadual do Ceará, Brasil http://orcid.org/0000-0002-8029-5907 vitoriacherida91@gmail.com

Recebido: 13/08/2020 Revisado: 20/08/2020 Aceito: 20/08/2020 Publicado: 01 /11 /2020

Autores: Lia Machado Fiauza Fialho, José Gerardo Vasconcelos y José Rogério Santana (Orgs.)

Editora: EdUECE, Brasil

Ano: 2015

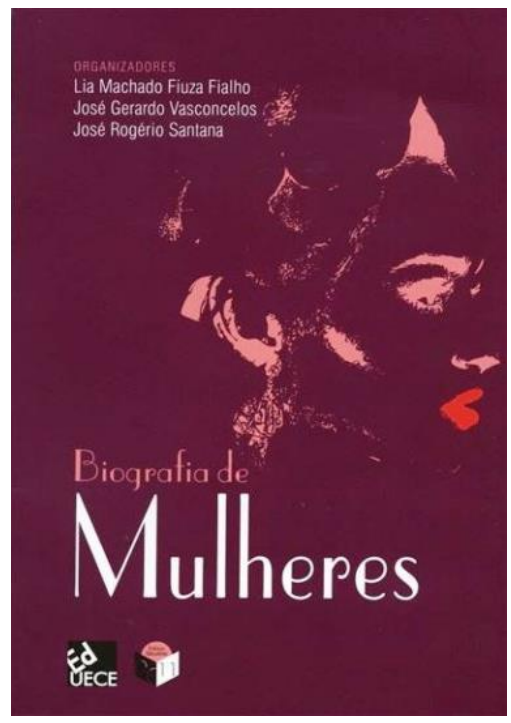

Como cita esta resenha: Sousa, A. C. B., Ferreira, M.C. y Costa, V.C. (2020). Resenha. Biografia de Mulheres. Hachetetepé. Revista científica en Educación y Comunicación, (21), 98100. https://doi.org/10.25267/Hachetetepe.2020.i21.10

O livro apresenta contextos de mulheres que tiveram suas presenças marcadas por lutas e resistências registradas em biografias, configurando um desafio investigativo renovado, sob diversas perspectivas teóricas e metodológicas, possibilitando a 
visibilidade dessas mulheres que estavam no silêncio histórico. $\mathrm{O}$ método biográfico permite compreender os caminhos indissociáveis das mulheres como sujeitos ativos na sociedade, contribuindo assim com um novo olhar sobre o gênero feminino e suas vinculações aos diversos cenários da história brasileira. O livro conta o percurso de mulheres tomando como ponto de análise suas relações com a instrução feminina, $o$ pioneirismo do movimento feminista, as trajetórias educacionais, bem como as relações de gênero e a biografia como método históriográfico. A obra expõe relatos e trajetórias que envolvem a especificidade das biografadas no imbricamento com seus contextos histórico-sociais, exemplificados na relação com a capoeira e sua cultura (p. 72), na morte de dois jovens na conjuntura da sociedade patriarcal e machista do estado paraibano do século XX (p. 87), na narrativa sobre a ciência e a política representada através da biografia de uma feminista (p. 109), nas experiências formativas de uma educadora freiriana (p. 123), ou ainda na memória de uma militante política no contexto histórico pós-golpe militar de 1964 (p. 138).

Percebe-se na obra as referências de como os autores fizeram o levantamento e o tratamento das fontes, sobretudo das fontes orais, do uso de livros e outros registros de memórias. Relaciona-se através do método biográfico a dialética entre o contexto social e a atuação de aproximação ou distanciamento do indivíduo em determinado contexto. A biografias são pertinentes para tratar de temas como cultura, personalidade, gerações e gênero.

O primeiro capítulo retrata as contribuições de Ana de Barandas em estudos sobre gênero, divórcio e educação feminina, e em inserções nas narrativas históricas da guerra de farrapos. A pesquisa utiliza a metodologia da história oral complementada com outras fontes documentais e imagéticas, artigos científicos e livros. Propõe compreender a relação entre a biografada e o ensino feminino, a formação de professores e a importância da educadora Barandas como precursora de ideias feministas. Além disso, o capítulo ressalta a participação significativa da biografada para a história da educação, mediante análise das nuances e possibilidades da educação feminina no Rio Grande do Sul do século XIX.

O segundo capítulo desvela a biografia de Piedade Medeiros e o elo com a história da educação na Paraíba. Sua contribuição se deu na publicação de livros didáticos sobre a cultura regional. A abordagem teórico-metodológica utilizada pelos autores se ancoram na nova história cultural e na história oral, que auxiliam na organização das narrativas da biografada, Piedade Medeiros. Define o percurso metodológico da história oral referenciado em Delgado (2006) e a dimensão das ausências de pesquisas sobre mulheres a partir do olhar de Barcelar (2006), que ressalta a intencionalidade em negar e excluir o estudo sobre mulheres propositadamente, para atender ao interesse hegemônico masculino.

No terceiro capítulo, o autor Rodrigues desenvolve uma associação entre biografia e gênero. Parte da proposição de que a biografia como gênero histórico e literário foi negligenciada pela academia, porém, que o grande interesse do público prestigiou a produção desse gênero. $\mathrm{O}$ autor apresenta o sentido metonímico da biografia, onde buscase conhecer o todo (a sociedade) pelas partes (os individuos com suas singularidades e diferentes atuações). Divide os tipos de biografias entre personalistas, contextualizadas historicamente ou das elites (p.58). Infere que a biografia é uma metodologia com potencialidade de diálogo entre o individual e o social (p. 61) e que, com os estudos 
biográficos têm-se a compreensão da sociedade, da cultura e da ação social dos sujeitos em interação com as estruturas sociais.

O quarto capítulo trata da história da capoeira no Ceará, a partir da trajetória de vida da educadora Lúcia Vanda Rodrigues e o reconhecimento da sua luta também na área educacional. Propõe a compreensão do estudo biográfico como possibilidade para a escrita histórica. O quinto capítulo analisa a perspectiva teórico-metodológica da microhistória a partir do crime que levou a morte dos jovens Sady e Ágaba na Paraíba em 1923. Através do prisma do autor Boris Fausto (2009) e suas percepções sobre a escala, a concentração desta em pessoas comuns demonstra a possibilidade de extrair de fatos corriqueiros uma dimensão socio-cultural relevante. Nesta perspectiva, a autora interrelaciona os costumes desfavoráveis a presença da mulher na vida pública, a influência da igreja católica na educação, o contexto de casamentos arranjados e o desenlace trágico da história narrada.

O sexto capítulo disserta sobre a trajetória política da feminista Bertha Lutz e sua atuação no campo educacional e na produção científica. Expõe o ideal da biografada em construir uma nova função social femenina, através da instrução, calcada na ciência e na educação. Destaca as lutas por direito ao voto e a defesa da inclusão da mulher no mercado de trabalho, além de suas proposições no campo científico, museológico e participação na política.

O capítulo sete analisa as disputas de poder na formação de professores da Educação de Jovens e Adultos no vale do Jaguaribe-CE no contexto histórico do golpe de 1964, a partir da transição e do confronto de projetos de alfabetização como o método Paulo Freire e o projeto MOBRAL. A desobediência narrada pela biografada, contrariando as regras vigentes para "desenvolver a criticidade dos alunos" (p. 129) aponta o desejo de revolução e resistência dos grupos ameaçados pelo contexto ditatorial em manter a perspectiva freiriana de ensino.

O capítulo oito encerra a obra analisando as memórias de uma militante de esquerda no contexto pós 1964, a partir da concepção que o autor Benjamin (1994) denomina "história dos vencidos", que segundo ele possibilitaria aos excluídos da história a conquista da palavra (p.138).

\section{REFERÊNCIA BIBLIOGRÁFICA}

Fialho, L. M. F., Vasconcelos, J.G. y Santana, J. R. (2015). Biografia de mulheres. Brasil: EdUECE. 